\title{
The Reality of the use of Fencing Course Faculty Members for virtual electronic educational platforms in some faculties of Physical Education
}

Dr/ Dr/ Rasha Farag Masoud Al-Arabi

Introduction and research Problem

The world is witnessing a great event, The Corona pandemic, since its discovery in China in December 2019, and the new Corona virus is still a challenge to the international community and has had many health, economic and social impacts, and it had the greatest impact on the educational process, as students stopped continuing education in schools based on State instructions to ensure their safety and to prevent the spread of the virus.

Technology has become one of the basic elements for developing educational and educational systems, and improving the various tasks of the teaching and learning process through systems theory and the concept of systems means that it is a group of parts that interact together in order to achieve one or more goals, and the systems method is the infrastructure for educational technology and the use of the systems method In the field of education, to change the perception of modern technological means, such as computers, educational television, closed circuit television, and educational films, as they are merely educational means, to consider them as organic elements in the education and training technology system as a system within the general educational system. (26: 8) (28: 12).

The E-learning process aims to create an interactive teaching and learning environment through various electronic technologies that help improve inputs and raise teachers 'capabilities in employing these technologies to formulate educational content and activities in a way that meets scientific and educational quality standards, and develops students' tendencies and positive attitude towards more education and learning.

Hence The importance of digital learning and the emergence of educational platforms that provide distance education and it is one of the most important means of E-learning as it provides educational courses form the Internet.

Providing the opportunity for learners to communicate and interact with each other during learning, and the communication theory emphasizes digital learning via networks and the use of computer technology and the Internet in learning. (2)

The educational platforms are based on the principles of communicative theory presented by both Siemens and Owens, so the communicative learning theory is consistent with the constructivist theory in emphasizing social learning,

As Yu, Y. (2016), Wang, F. (2017), Liu, J. (2018) point out that contemporary global trends indicate the enormous diversity and richness in the use of digital platforms, as they present digital content in an interesting way. Effective, it helps in developing

Assiut Journal For Sport Science Arts 
curricula and methods of teaching and evaluation, improving the educational environment that stimulates innovation, provides students with remote education anytime and anywhere, and provides its educational services to all segments of society. And considering that students in university education are the main factor and effective element in use and because students have the ability to use digital platforms through computers, tablets, smart phones, etc., and they have a high level of technical competence, and that they have the ability to show their strengths and weaknesses (26), (25), (24).

Since the beginning of the Corona pandemic, countries have closed all educational institutions to limit the spread of this dangerous disease, and so governments have used educational platforms, which is a modern thing that students in general and teachers in particular have not been trained in, so there were many obstacles facing teachers, including how to deal with platforms and how to spread The educational content, how to photograph the explanation of the student, and how to communicate with them during the explanation.

Through reviewing previous Arabic studies such as the study of AlQahtani, Ibtisam Saeed (2010) (6), Al-Sayyid Abd al-Aal Abdullah (2015) (7), Al-Dossari Muhammad Salem (2016) (3), Al-Enezi Yusef Abd al-Majeed (2017) (4 ), AlHamad Hanan Abdulaziz Saud (2019) (5),Al-Rashidy Munira Shuqair (2019) (15), and foreign studies such as Armitage, J. (2011)
(17), Baker, R. \& other (2018). 18), Chung, CH \& other (2018) (19), Zhu, C. (2018) (30). These studies called for attention to training and qualifying Teachers to use electronic educational platforms, encouraging them to use them, addressing deficiencies in educational platforms and removing obstacles in order to allow purpose and knowledge for all learners.

The sport of fencing is one of the individual sports that require high accuracy and focus and need physical skills such as speed, accuracy and agility, and it requires a high reaction and is considered one of the concessions that require effort and training to reach the high level.

Through the work of the researcher at the Faculty of Physical Education at Sadat City University and her teaching of the fencing course for female students and in light of the conditions that society is going through, the difficulty of organizing in traditional education and resorting to distance learning. Virtualization in the field of physical education,

And through conducting an exploratory study on the electronic platforms available to students, the researcher found that there are obstacles in using the educational platforms for both the teacher and the student and this matter which attracted the researcher to know the current situation of using virtual electronic platforms in teaching the fencing course and The causes of these obstacles and the attempt to present solutions to reach appropriate results and recommendations for developing 
curricula, teaching methods and teaching methods, and providing the teaching staff with educational decisions, and this prompted the researcher to identify the reality of the use of fencing course faculty members for virtual electronic educational platforms in some faculties of physical education.

\section{Research goal}

The research aims to identify the reality of the use of fencing course faculty members on the virtual electronic educational platforms of some physical education colleges through the following axes- :

1-The importance of using virtual electronic educational platforms in teaching the fencing course to male and female students of some physical education colleges.

2-The extent of using virtual electronic educational platforms in teaching the fencing course to male and female students of some physical education colleges.

3-Difficulties facing the use of virtual electronic educational platforms in teaching the fencing course to male and female students of some physical education colleges.

4-Setting a proposed concept for developing and activating the virtual electronic educational platforms in the Faculties of Physical Education.

\section{Research Questions}

1- What is the importance of using virtual educational platforms in teaching the fencing course to male and female students of some physical education colleges?

2-What is the extent of using virtual educational platforms in teaching the fencing course to male and female students of some physical education colleges?

What are the difficulties facing the use of virtual electronic educational platforms in teaching the fencing course to male and female students of some physical education colleges?

4- What is the proposed scenario for developing and activating the virtual electronic educational platforms in the Faculties of Physical Education?

\section{Research Terms}

\section{Electronic Educational Platforms:}

"Tamer Al Mallah" defines it as an interactive learning environment that employs web technology and combines the advantages of electronic content systems with Facebook social networks. It enables learners to publish lessons and goals, set assignments, implement educational activities and contact teachers through multiple technologies. It also enables electronic tests and distribution. Roles and the division of students into working groups and help in exchanging ideas and opinions between teachers and students, which helps in achieving high quality educational outcomes. (5:80)

The researcher defines it procedurally as virtual classes that depend on the meeting of learners and teachers at different times for work. They are similar to traditional classes in terms of the presence of the teacher and the learner on the Internet, so that they are not restricted to a time or place and through them, virtual educational classes are created.

\section{Fencing:}

It is the sport of attack and defense using the three weapons, "The 
Foil - The Epee - The Saber", the aim is to achieve a correct touch on the opponent and prevent him from achieving this by using the appropriate technical skills in order to win the match. (15:16)

It is also known as a competition between two players, each competing against the other, by facing the front with their sword, exchanging attack, defense and response while advancing forward, or retreating behind in a continuous movement for each of them, trying to score a touch with the front of his sword in the legal goal. (1:37)

\section{Research Procedures \\ Research Methodology}

The researcher used the descriptive method "survey studies" due to its relevance to the nature of the study.

\section{Research Community:}

The research community is represented by faculty members in the Fencing Division, in the Department of Competitions and Water Sports,

Table (1)

Distribution of The Community and The Research Sample for the Faculties of Physical Education for boys and girls in the Arab Republic of Egypt

\begin{tabular}{|c|c|c|c|}
\hline \multirow{2}{*}{$\mathbf{S}$} & \multirow{2}{*}{ College Name } & \multicolumn{2}{|c|}{$\begin{array}{l}\text { Faculty members, } \\
\text { "Fencing Division," }\end{array}$} \\
\hline & & $\begin{array}{c}\text { basic } \\
\text { sample }\end{array}$ & $\begin{array}{l}\text { An } \\
\text { exploratory }\end{array}$ \\
\hline 1 & Faculty of Physical Education for Boys - Helwan University & 3 & 1 \\
\hline 2 & $\begin{array}{l}\text { Faculty of Physical Education for Boys - Alexandria } \\
\text { University }\end{array}$ & 2 & - \\
\hline 3 & Faculty of Physical Education for Boys Zagazig University & 2 & 1 \\
\hline 4 & Faculty of Physical Education for Boys - Benha University & 2 & 1 \\
\hline 5 & $\begin{array}{l}\text { Faculty of Physical Education in Al-Jazeera Girls - Helwan } \\
\text { University }\end{array}$ & 3 & 1 \\
\hline 6 & $\begin{array}{l}\text { Faculty of Physical Education for Girls - Zagazig } \\
\text { University }\end{array}$ & 2 & 1 \\
\hline 7 & $\begin{array}{l}\text { Faculty of Physical Education for Girls - } \\
\text { Alexandria University }\end{array}$ & 2 & - \\
\hline
\end{tabular}

Individual Sports, Individual Sports Training, or the Theories and Applications of Competitions and Water Sports in some Colleges of Physical Education for Boys and Girls in the Arab Republic of Egypt.

\section{The Research Sample}

The research sample was deliberately chosen from the faculty members of some physical education colleges for boys and girls at the level of the Arab Republic of Egypt in the academic year 2019/2020 AD, where the total research community reached (49) members, the basic research sample reached (40) and the exploratory research sample reached a number (9) Members as a sample to codify the basic research tool, "the questionnaire", from the same community and outside the main sample. Table (1) shows the distribution of the research sample.

\section{Assiut Journal For Sport Science Arts}


Foolow Table (1)

Distribution of The Community and The Research Sample for the Faculties of Physical Education for boys and girls in the Arab Republic of Egypt

\begin{tabular}{l|l|c|c}
\hline \hline \multirow{2}{*}{$\mathbf{s}$} & \multicolumn{1}{c|}{ College Name } & \multicolumn{2}{c}{$\begin{array}{c}\text { Faculty members, } \\
\text { "Fencing Division," }\end{array}$} \\
\cline { 3 - 4 } & & $\begin{array}{c}\text { Ansic } \\
\text { sample }\end{array}$ & $\begin{array}{c}\text { Anploratory } \\
\text { explon }\end{array}$ \\
\hline \hline 8 & Faculty of Physical Education - Assiut University & 2 & - \\
\hline 9 & Faculty of Physical Education- Mansoura University & 1 & - \\
\hline 10 & Faculty of Physical Education- Sadat City University & 3 & 1 \\
\hline 11 & Faculty of Physical Education - Kafr El Sheikh University & 1 & 1 \\
\hline 12 & Faculty of Physical Education - Minia University & 1 & 1 \\
\hline 13 & Faculty of Physical Education - Port Said University & 2 & - \\
\hline 14 & Faculty of Physical Education - Beni Suef University & 2 & - \\
\hline 15 & Faculty of Physical Education - Menoufia University & 2 & - \\
\hline 16 & Faculty of Physical Education - Suez Canal University & 2 & 1 \\
\hline 17 & Faculty of Physical Education - Tanta University & 3 & - \\
\hline 18 & Faculty of Physical Education - Fayoum University & 2 & - \\
\hline 19 & Faculty of Physical Education for Boys - Damietta University & 2 & - \\
\hline 20 & Faculty of Physical Education for Girls - Damietta University & 1 & 9 \\
\hline Total & & 40 & \\
\hline \hline
\end{tabular}

\section{Tools and Data Collection:}

The researcher used the following tools and means to collect data related to the research, as follows:

1- Reference survey of scientific references and previous studies on the subject of the study .

2- Personal interviews.

3- Questionnaire designed by the researcher.

\section{Questionnaire design steps:}

The researcher designed the questionnaire according to the following:

1-Preliminary procedures:

Determine the main themes and phrases for each axis based on what has been learned from the following sources:

- $\quad$ Scientific references and studies related to the subject of the study.
- Personal interview with several faculty members who specialize in teaching the fencing course in some colleges of physical education for boys and girls.

- A survey of the opinions of experts specializing in fencing and methods of teaching physical education. Attachment(1).

Accordingly, the researcher designed the questionnaire form in its initial form attachment (2) by following the following steps:

A- Defining (3) axes according to the reference survey, previous studies and personal interviews, and presenting them to the experts. Table (2) shows the percentage of opinions of the experts on the axes of the questionnaire in their initial form. 
Table (2)

The percentage of opinions of the experts on the axes of the questionnaire in its initial form, $\mathbf{N}=\mathbf{1 0}$

\begin{tabular}{c|l|c}
\hline \hline The axis & \multicolumn{1}{|c|}{ The named axis } & $\begin{array}{c}\text { Percentage } \\
\text { Axis }\end{array}$ \\
\hline \hline First & $\begin{array}{l}\text { The importance of using virtual educational platforms in teaching } \\
\text { the fencing course to male and female students of some physical } \\
\text { education colleges. }\end{array}$ & $100 \%$ \\
\hline Second & $\begin{array}{l}\text { The extent of using virtual educational platforms in teaching the } \\
\text { fencing course to male and female students of some physical } \\
\text { education colleges. }\end{array}$ & $100 \%$ \\
\hline Third & $\begin{array}{l}\text { Difficulties facing the use of virtual educational platforms in } \\
\text { teaching the fencing course to male and female students of some } \\
\text { physical education colleges }\end{array}$ & $100 \%$ \\
\hline \hline
\end{tabular}

B- The researcher presented the content of the questionnaire in its initial form to (10) experts specialized in fencing and methods of teaching physical education in order to determine the appropriate and accurate formulation of phrases for each axis and the appropriate scale of assessment for the form.

C- This resulted in some amendments proposed by the experts

Table (3)

Limiting the agreement of experts' opinions on defining the terms of the questionnaire from its initial to its final form

\begin{tabular}{|c|c|c|c|c|c|c|}
\hline \multirow{2}{*}{$\mathbf{S}$} & \multirow[t]{2}{*}{ Axis } & \multirow{2}{*}{$\begin{array}{c}\text { Initial } \\
\text { number }\end{array}$} & \multicolumn{3}{|c|}{ Number of phrases } & \multirow{2}{*}{$\begin{array}{l}\text { Final } \\
\text { number }\end{array}$} \\
\hline & & & Delete & Add & Edit & \\
\hline 1 & $\begin{array}{l}\text { The importance of using virtual } \\
\text { educational platforms in teaching the } \\
\text { fencing course to male and female students } \\
\text { of some physical education colleges. }\end{array}$ & 26 & 6 & - & 7 & 20 \\
\hline 2 & $\begin{array}{l}\text { The extent of using virtual educational } \\
\text { platforms in teaching the fencing } \\
\text { course to male and female students of } \\
\text { some physical education colleges. }\end{array}$ & 16 & 4 & - & 5 & 12 \\
\hline 3 & $\begin{array}{l}\text { Difficulties facing the use of virtual } \\
\text { educational platforms in teaching the } \\
\text { fencing course to male and female students } \\
\text { of some physical education colleges }\end{array}$ & 18 & 5 & - & 6 & 13 \\
\hline & Total & 59 & 15 & - & 18 & 45 \\
\hline
\end{tabular}

where some expressions were deleted to repeat the meaning, reformulation of some phrases for lack of interpretation of more than one meaning, following a triple scale of assessment (yes, to some extent, no), and thus the list became in its final form attached (4), and the questionnaire consists of (3) axes and includes (45) phrases as follows:

Assiut Journal For Sport Science Arts 
In light of the opinions of the experts, the researcher made the necessary adjustments that were unanimously agreed upon by the experts, and the researcher agreed with $80 \%$ as a minimum to accept the phrase.

\section{First: The Honesty Factor}

To verify the questionnaire, the researcher used the validity of the content that depends on the questionnaire's representation of the field in which he is analyzing and

Table (4)

The percentage of validity of the content according to the opinions of The Experts on the axes of The questionnaire

\begin{tabular}{c|l|c}
\hline \hline The axis & The named axis & $\begin{array}{c}\text { Percentage } \\
\text { Axis }\end{array}$ \\
\hline \hline First & $\begin{array}{l}\text { The importance of using virtual educational platforms in } \\
\text { teaching the fencing course to male and female students } \\
\text { of some physical education colleges. }\end{array}$ & $90 \%$ \\
\hline Second & $\begin{array}{l}\text { The extent of using virtual educational platforms in } \\
\text { teaching the fencing course to male and female students } \\
\text { of some physical education colleges. }\end{array}$ & $100 \%$ \\
\hline Third & $\begin{array}{l}\text { Difficulties facing the use of virtual educational } \\
\text { platforms in teaching the fencing course to male and } \\
\text { female students of some physical education colleges }\end{array}$ & $90 \%$ \\
\hline \hline
\end{tabular}

It is shown from Table (4) that the majority of experts assert that the questionnaire measures what it has been designed for, and thus the veracity of the content of the axes and expressions of the questionnaire has been verified.

Second: The Stability Factor.

To calculate coefficients, the researcher used the method of application and then re-application to the exploratory sample consisting of evaluating, as the questionnaire was presented to a group of experts in fencing and methods of teaching physical education to find out their views on whether the questionnaire measured the various aspects for which it was developed and through its themes and phrases According to the opinion of the majority, the phrases in the questionnaire were modified and phrased in the period 1/6/2020 until $10 / 6 / 2020$, and it is clear from Table (4).
(9) individuals from the research community and outside the research sample from the faculty members of the "Fencing Division". The application was carried out on $20 / 6 / 2020$ and the application was repeated on 2/7/2020 with a difference. A time frame of (12) days and the simple correlation coefficient between the first and second applications was found, and Table (5) illustrates this. 
Table (5)

The reliability factor of the questionnaire form $\mathrm{N}=\mathbf{1 0}$

\begin{tabular}{c|l|c}
\hline \hline The axis & \multicolumn{1}{|c|}{ The named axis } & "C" Value \\
\hline \hline First & $\begin{array}{l}\text { The importance of using virtual educational platforms in } \\
\text { teaching the fencing course to male and female students } \\
\text { of some physical education colleges. }\end{array}$ & $0.788^{*}$ \\
\hline Second & $\begin{array}{l}\text { The extent of using virtual educational platforms in } \\
\text { teaching the fencing course to male and female students } \\
\text { of some physical education colleges. }\end{array}$ & $0.812^{*}$ \\
\hline Third & $\begin{array}{l}\text { Difficulties facing the use of virtual educational } \\
\text { platforms in teaching the fencing course to male and } \\
\text { female students of some physical education colleges }\end{array}$ & $0.865^{*}$ \\
\hline \multicolumn{2}{c}{ Total } & $0.812^{*}$ \\
\hline \hline
\end{tabular}

The tabular "C" value is at the level of $0.05=0.632$.

It is shown from Table (5) that there is a statistically significant correlation relationship (0.05) between the first and second applications of all axes of the questionnaire "under research," indicating that it has a high reliability coefficient.

Application of the questionnaire form

After verifying the validity of the questionnaire form to achieve the goal of the research, and putting it in its final form, which included (3) axes and included (45) phrases, and the questionnaire was sent to the faculty members, the basic research sample of (40) members, in the period of

Table (6)

4/7/2020 AD until 20/7/2020, electronically, through the following link:

https://docs.google.com/document/d/1DCXhUf 0skRiLKQ_BOiiaUcuXQUinBI5I/edit

Statistical Treatments:

Simple correlation coefficient, frequencies, percentages, $\mathrm{Ca} 2$ test. Relative importance, Relative weight.

Presentation and Discussion of Results

First: The first axis: "What is the importance of using virtual electronic educational platforms in teaching the fencing course to male and female students of some physical education colleges"?

Frequencies, Percentages, Relative Importance, Relative Weight, and Coefficient

(Ca2) for responses of respondents on the importance of using virtual educational platforms in teaching the Fencing Course For male and female students of some Faculties of Physical Education $\mathbf{N}=\mathbf{4 0}$

\begin{tabular}{c|c|c|c|c|c|c|c|c|c|c}
\hline \hline S & \multirow{2}{*}{ Phrases } & \multicolumn{2}{|c|}{ Yes } & \multicolumn{2}{|c|}{ Rather } & \multicolumn{2}{|c|}{ No } & Relative & Relative & Ca2 \\
Imp. & Weight & \\
\hline \hline 1 & $\begin{array}{l}\text { The student feels } \\
\text { responsible in the } \\
\text { classroom dialogue }\end{array}$ & 28 & 70 & 9 & 22.5 & 3 & 7.5 & 105 & 0.88 & $25.55^{*}$ \\
\hline 2 & $\begin{array}{l}\text { Provides the learner } \\
\text { with an atmosphere of } \\
\text { privacy in learning }\end{array}$ & 33 & 82.5 & 5 & 12.5 & 2 & 5 & 111 & 0.93 & $43.86^{*}$ \\
\hline \hline
\end{tabular}

Assiut Journal For Sport Science Arts 
Foolow Table (6)

Frequencies, Percentages, Relative Importance, Relative Weight, and Coefficient

(Ca2) for responses of respondents on the importance of using virtual

educational platforms in teaching the Fencing Course For male and female students of some Faculties of Physical Education $\mathbf{N}=\mathbf{4 0}$

\begin{tabular}{|c|c|c|c|c|c|c|c|c|c|c|}
\hline \multirow[t]{2}{*}{$\mathbf{S}$} & \multirow[t]{2}{*}{ Phrases } & \multicolumn{2}{|c|}{ Yes } & \multicolumn{2}{|c|}{ Rather } & \multicolumn{2}{|c|}{ No } & \multirow{2}{*}{$\begin{array}{l}\text { Relative } \\
\text { Imp. }\end{array}$} & \multirow{2}{*}{$\begin{array}{c}\text { Relative } \\
\text { Weight }\end{array}$} & \multirow[t]{2}{*}{$\overline{\mathrm{Ca2}}$} \\
\hline & & $\mathrm{F}$ & $\%$ & $\mathrm{~F}$ & $\%$ & $\mathrm{~F}$ & $\%$ & & & \\
\hline 3 & $\begin{array}{l}\text { To develop students' } \\
\text { self-learning skills }\end{array}$ & 37 & 92.5 & 3 & 7.5 & 0 & 0 & 117 & 0.98 & $63.36^{*}$ \\
\hline 4 & Helps to learn mastery & 28 & 70 & 7 & 17.5 & 5 & 12.5 & 103 & 0.86 & $24.35^{*}$ \\
\hline 5 & $\begin{array}{l}\text { Encourages } \\
\text { cooperative learning }\end{array}$ & 34 & 85 & 5 & 12.5 & 1 & 2.5 & 113 & 0.94 & $48.66^{*}$ \\
\hline 6 & $\begin{array}{l}\text { It meets students' } \\
\text { learning needs }\end{array}$ & 20 & 50 & 15 & 37.5 & 5 & 12.5 & 95 & 0.79 & $8.75^{*}$ \\
\hline 7 & $\begin{array}{l}\text { Achieve a better level } \\
\text { of traditional education }\end{array}$ & 33 & 82.5 & 5 & 12.5 & 2 & 5 & 111 & 0.93 & $43.86^{*}$ \\
\hline 8 & $\begin{array}{l}\text { Help for continuous } \\
\text { learning }\end{array}$ & 21 & 52.5 & 19 & 47.5 & 0 & 0 & 101 & 0.84 & $20.15^{*}$ \\
\hline 9 & $\begin{array}{lrr}\text { It provides students } & \begin{array}{r}\text { with } \\
\text { opportunities } \\
\text { to } \\
\text { informattain } \\
\text { sources }\end{array} & \begin{array}{r}\text { obtam } \\
\text { multiple }\end{array} \\
\end{array}$ & 35 & 87.5 & 5 & 12.5 & 0 & 0 & 115 & 0.96 & $53.76^{*}$ \\
\hline 10 & $\begin{array}{ll}\text { Students' } & \text { individual } \\
\text { differences } & \text { are } \\
\text { into account } & \\
\end{array}$ & 22 & 55 & 16 & 40 & 2 & 5 & 100 & 0.83 & $15.80^{*}$ \\
\hline 11 & $\begin{array}{l}\text { Developing scientific } \\
\text { thinking skills }\end{array}$ & 36 & 90 & 3 & 7.5 & 1 & 2.5 & 115 & 0.96 & $57.96^{*}$ \\
\hline 12 & $\begin{array}{l}\text { Various evaluation } \\
\text { methods can be applied to } \\
\text { students }\end{array}$ & 36 & 90 & 4 & 10 & 0 & 0 & 116 & 0.97 & $58.41 *$ \\
\hline 13 & $\begin{array}{l}\text { It increases the teaching } \\
\text { efficiency of faculty } \\
\text { members }\end{array}$ & 30 & 75 & 8 & 20 & 2 & 5 & 108 & 0.9 & $32.61 *$ \\
\hline 14 & $\begin{array}{l}\text { It reduces the effort } \\
\text { expended by both faculty } \\
\text { members and students }\end{array}$ & 32 & 80 & 6 & 15 & 2 & 5 & 110 & 0.92 & $39.81^{*}$ \\
\hline 15 & $\begin{array}{l}\text { It develops students' } \\
\text { psychological skills, such } \\
\text { as mental perception and } \\
\text { attention focus }\end{array}$ & 27 & 67.5 & 5 & 12.5 & 8 & 20 & 99 & 0.82 & $21.36^{*}$ \\
\hline 16 & $\begin{array}{l}\text { Provide visual and } \\
\text { auditory feedback to } \\
\text { the student }\end{array}$ & 28 & 70 & 10 & 25 & 2 & 5 & 106 & 0.88 & $26.06^{*}$ \\
\hline 17 & $\begin{array}{l}\text { Lead to providing students } \\
\text { with theoretical knowledge } \\
\text { and information }\end{array}$ & 36 & 90 & 4 & 10 & 0 & 0 & 116 & 0.97 & $58.41 *$ \\
\hline 18 & $\begin{array}{l}\text { Attracts the student's attention } \\
\text { to the small details of an } \\
\text { educational situation }\end{array}$ & 33 & 82.5 & 0 & 0 & 7 & 17.5 & 106 & 0.88 & $45.36^{*}$ \\
\hline 19 & $\begin{array}{l}\text { The possibility of } \\
\text { formulating activities that } \\
\text { help students develop } \\
\text { their cognitive abilities }\end{array}$ & 35 & 87.5 & 5 & 12.5 & 0 & 0 & 115 & 0.96 & $53.76^{*}$ \\
\hline 20 & $\begin{array}{l}\text { It works to achieve the goals } \\
\text { of the educational process }\end{array}$ & 32 & 80 & 8 & 20 & 0 & 0 & 112 & 0.93 & $41.61^{*}$ \\
\hline
\end{tabular}

"Ca2" value at the level of significance $0.05=(5.99)$.

Assiut Journal For Sport Science Arts 


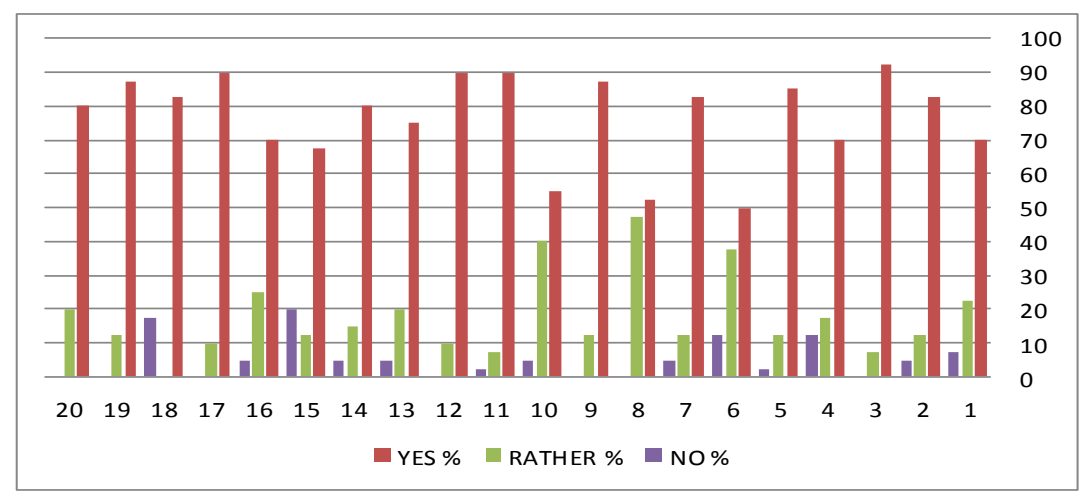

Figure (1)

The Percentage of Frequencies of The expressions of The First Axis.

It is clear from Table (6) and

Figure (1) that the frequencies, percentages, Relative Importance, Relative Weight, and The Coefficient (Ca2) of the responses of the sample individuals about the importance of using virtual educational platforms in teaching the fencing course to students of some faculties of physical education. They say (Yes) between (20:37) and a percentage (50\%:92.5\%), and the frequency and percentage of faculty members who answered (Rather) were limited between (0: 19) and with a percentage (0\%:47.5), The frequency and percentages of faculty members who answered (No) were limited to $(0: 8)$ and with a percentage (0\%:20\%). The calculated $\mathrm{Ca} 2$ value ranged between (8.75: 63.36) greater than its tabular value (5.99). At a degree of freedom (2), at a level of significance (0.05) in all expressions of the first axis.

This indicates the approval of the faculty members to the phrases of the first axis about the importance of virtual electronic educational platforms. The researcher believes that the highest phrases in the first axis that have been approved are " To develop students' self-learning skills " while the least statements that were not approved are " It meets students' learning needs"and this indicates the importance of virtual electronic educational platforms in teaching as they work to achieve the goals of the educational process, attract students' attention, and work to impart skills, knowledge and theoretical information while students rely on traditional learning and do not meet their needs sufficiently.

It agrees with the study of AlQahtani, Ibtisam Saeed (2010) (6), Al-Sayyid Abd al-Aal Abdullah (2015) (7), Al-Dossari Muhammad Salem (2016) (3), Al-Enezi Yusef Abd al-Majeed (2017) (4 ), AlHamad Hanan Abdulaziz Saud (2019) (5),Al-Rashidy Munira Shuqair (2019) (15), Armitage, J. (2011) (17), Baker, R. \& other (2018). 18), Chung, CH \& other (2018) (19), Zhu, C. (2018) (30). On the effectiveness and importance of educational platforms in upgrading the cognitive and practical aspects and 
improving students' theoretical concepts.

The approval of the faculty members on the importance of virtual educational platforms in teaching the fencing course in some faculties of physical education was of a high degree, and this result is consistent with the findings of the study of Tamam , Shadia Abdel Halim (2018) (16) that the virtual classroom has a great positive impact on the development of simultaneous and nonsimultaneous interaction Synchronous between teachers and learners as it enables the learner to read educational lessons, solve assignments and

Table (7)

Frequencies, Percentages, Relative Importance, Relative Weight, Coefficient (Ca2) for responses about the extent of using virtual electronic educational platforms in teaching the fencing course for male and female students of some physical education colleges $\mathrm{N}=\mathbf{4 0}$

\begin{tabular}{|c|c|c|c|c|c|c|c|c|c|c|}
\hline \multirow[t]{2}{*}{$\overline{\mathbf{S}}$} & \multirow[t]{2}{*}{ Phrases } & \multicolumn{2}{|c|}{ Yes } & \multicolumn{2}{|c|}{ Rather } & \multicolumn{2}{|c|}{ No } & \multirow{2}{*}{$\begin{array}{c}\text { Relative } \\
\text { Imp. } \\
\end{array}$} & \multirow{2}{*}{$\begin{array}{c}\text { Relative } \\
\text { Weight }\end{array}$} & \multirow[t]{2}{*}{ Ca2 } \\
\hline & & $\mathbf{F}$ & $\%$ & $\mathbf{F}$ & $\%$ & $\mathbf{F}$ & $\%$ & & & \\
\hline 1 & $\begin{array}{l}\text { The platforms are } \\
\text { easy to use and } \\
\text { accessible } \\
\text { everyone }\end{array}$ & 23 & 57.5 & 12 & 30 & 5 & 12.5 & 98 & 0.82 & $12.35 *$ \\
\hline 2 & $\begin{array}{ll}\text { It is taught to } \\
\text { students } & \text { in } \\
\text { traditional methods }\end{array}$ & 8 & 20 & 2 & 5 & 30 & 75 & 58 & 0.48 & $32.60 *$ \\
\hline 3 & $\begin{array}{l}\text { There is a website } \\
\text { for the university }\end{array}$ & 14 & 35 & 5 & 12.5 & 21 & 52.5 & 73 & 0.6 & $9.65^{*}$ \\
\hline 4 & $\begin{array}{lc}\text { Students are taught } \\
\text { using } & \text { online } \\
\text { educational platforms }\end{array}$ & 10 & 25 & 4 & 10 & 26 & 65 & 64 & 0.53 & $19.40 *$ \\
\hline 5 & $\begin{array}{l}\text { It is difficult to rely } \\
\text { on electronic } \\
\text { platforms to teach } \\
\text { practical courses }\end{array}$ & 26 & 65 & 6 & 15 & 4 & 10 & 94 & 0.78 & $22.60 *$ \\
\hline 6 & $\begin{array}{l}\text { Electronic discussion } \\
\text { forums are used to } \\
\text { share experiences } \\
\text { with each other's } \\
\text { students }\end{array}$ & 20 & 50 & 0 & 0 & 20 & 50 & 80 & 0.67 & $20.00 *$ \\
\hline
\end{tabular}

Assiut Journal For Sport Science Arts activities, participate in discussion and dialogue forums, and see all the content first, and return to it at any time he wants. This answers the first question of the research, which states, "What is the importance of using virtual electronic educational platforms in teaching the fencing course to male and female students of some faculties of physical education?"

Second: The second axis: "What is the extent of using virtual electronic educational platforms in teaching the fencing course to male and female students of some physical education colleges?" 
Foolow Table (7)

Frequencies, Percentages, Relative Importance, Relative Weight, Coefficient (Ca2) for responses about the extent of using virtual electronic educational platforms in teaching the fencing course for male and female students of some physical education colleges $\mathrm{N}=\mathbf{4 0}$

\begin{tabular}{|c|c|c|c|c|c|c|c|c|c|c|}
\hline \multirow[t]{2}{*}{$\mathbf{S}$} & \multirow[t]{2}{*}{ Phrases } & \multicolumn{2}{|c|}{$\overline{\text { Yes }}$} & \multicolumn{2}{|c|}{ Rather } & \multicolumn{2}{|c|}{ No } & \multirow{2}{*}{$\begin{array}{c}\text { Relative } \\
\text { Imp. }\end{array}$} & \multirow{2}{*}{$\begin{array}{c}\text { Relative } \\
\text { Weight }\end{array}$} & \multirow[t]{2}{*}{ Ca2 } \\
\hline & & $\mathbf{F}$ & $\%$ & $\mathbf{F}$ & $\%$ & $\mathbf{F}$ & $\%$ & & & \\
\hline 7 & $\begin{array}{l}\text { Audio lectures are } \\
\text { recorded }\end{array}$ & 16 & 40 & 2 & 5 & 22 & 55 & 74 & 0.62 & $15.80 *$ \\
\hline 8 & $\begin{array}{l}\text { Assignments and } \\
\text { feedback are } \\
\text { received via the } \\
\text { online educational } \\
\text { platforms } \\
\text { Online educational }\end{array}$ & 5 & 12.5 & 4 & 10 & 31 & 44.5 & 54 & 0.45 & $35.16^{*}$ \\
\hline 9 & $\begin{array}{l}\text { platforms are used } \\
\text { to provide course } \\
\text { content to students }\end{array}$ & 5 & 12.5 & 10 & 25 & 25 & 62.5 & 60 & 0.5 & $16.25^{*}$ \\
\hline 10 & $\begin{array}{l}\text { Correcting exams } \\
\text { and scoring scores } \\
\text { via educational } \\
\text { platforms }\end{array}$ & 0 & 0 & 0 & 0 & 40 & 100 & 40 & 0.33 & $80.00 *$ \\
\hline 11 & $\begin{array}{l}\text { Students are } \\
\text { directed to digital } \\
\text { electronic } \\
\text { resources to obtain } \\
\text { information. }\end{array}$ & 6 & 15 & 5 & 12.5 & 19 & 47.5 & 47 & 0.39 & $11.65^{*}$ \\
\hline 12 & $\begin{array}{l}\text { The contents of the } \\
\text { course are viewed } \\
\text { through the } \\
\text { electronic } \\
\text { educational } \\
\text { platforms }\end{array}$ & 10 & 25 & 6 & 15 & 24 & 60 & 66 & 0.55 & $13.40 *$ \\
\hline 13 & $\begin{array}{l}\text { Course } \\
\text { examinations are } \\
\text { performed through } \\
\text { electronic } \\
\text { educational } \\
\text { platforms }\end{array}$ & 0 & 0 & 0 & 0 & 40 & 100 & 40 & 0.33 & $80.00 *$ \\
\hline
\end{tabular}

"Ca2" value at the level of significance $0.05=(5.99)$.

Assiut Journal For Sport Science Arts 


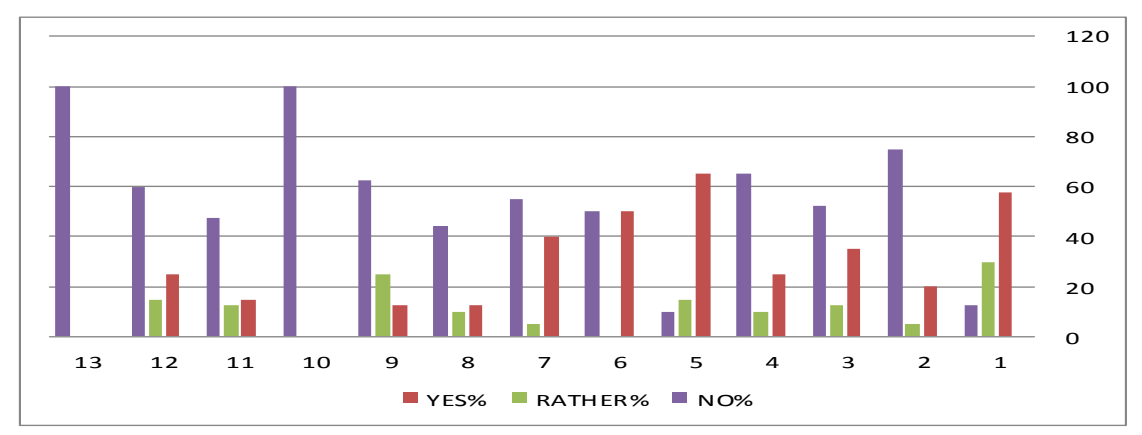

Figure (2)

The Percentage of Frequencies of The expressions of the Second Axis.

It is clear from Table (7) and

Figure (2) that The Frequencies, Percentages, Relative Importance, Relative Weight, and Coefficient (Ca2) for the responses of the sample individuals about the extent of using virtual electronic educational platforms in teaching the fencing course to male and female students of some faculties of physical education, "the second axis". (Yes) between (5: 26) and a percentage $(12.5 \%$ : 65\%), and the frequency and percentage of faculty members who answered (Rather) were limited between $(0: 12)$ and a percentage (0:30). The frequency and percentages of faculty members who answered (No) were limited to between (4:40) and with a percentage (10\%: $100 \%)$. The calculated $\mathrm{Ca} 2$ value ranged between (9.65: 80) greater than its tabular value (5.99). At a degree of freedom (2), at a level of significance $(0.05)$ in all expressions of the second axis.

Whereas, the highest approved expressions are the phrase "It is difficult to rely on electronic platforms in teaching practical courses" by $65 \%$ which is an average percentage, while the lowest approved expressions are the phrase "course exams are performed through the platform" with a zero percentage, as well as the phrase "correcting exams and recording grades through Educational platforms," at a percentage of zero, and this indicates the weakness of using virtual electronic educational platforms in teaching the fencing course to male and female students of some faculties of physical education."

The researcher returns this to the fact that the trends towards E-learning are few due to the lack of full awareness on the part of society about the principles of e-learning in addition to the reliance of colleges on traditional education systems as a result of not being able to cover the financial cost necessary to fully use elearning and the limited availability of the infrastructure that serves communications. From computers to laboratories and net networks, with the unavailability of electronic platforms that require high financial subscriptions, in addition to the lack of training of faculty members and students on the use of educational technology in the educational process. 
These results are consistent with the study of "Khamis , Muhammad Atiya (2018) (13) and Hassanein ,Mahdi Saeed (2011) (11) Omar, Laila El-Sayed (2000)(14), Armitage, J. (2018) (17) who pointed out the importance of providing data on educational technology and relying on it as a basis for education through which it facilitates interaction and learning processes at any time and place, supports collective and participatory work, and traces learners., And the delivery of content, resources, various educational

Table (8)

Frequencies, percentages, relative importance, relative weight, and coefficient

(Ca2) for responses of respondents about the difficulties facing the use of virtual electronic educational platforms in teaching the fencing course to male and female students of some physical education colleges , $N=40$

\begin{tabular}{|c|c|c|c|c|c|c|c|c|c|c|}
\hline \multirow[t]{2}{*}{$\mathbf{S}$} & \multirow[t]{2}{*}{ Phrases } & \multicolumn{2}{|c|}{ Yes } & \multicolumn{2}{|c|}{ Rather } & \multicolumn{2}{|c|}{ No } & \multirow{2}{*}{$\begin{array}{l}\text { Relati } \\
\text { ve } \\
\text { Imp. }\end{array}$} & \multirow{2}{*}{$\begin{array}{c}\text { Relati } \\
\text { ve } \\
\text { Weig } \\
\text { ht } \\
\end{array}$} & \multirow[t]{2}{*}{ Ca2 } \\
\hline & & $\mathbf{F}$ & $\%$ & $\mathbf{F}$ & $\%$ & $\mathbf{F}$ & $\%$ & & & \\
\hline 1 & $\begin{array}{l}\text { Students' lack of awareness of } \\
\text { the importance of electronic } \\
\text { educational platforms }\end{array}$ & 27 & 67.5 & 10 & 25 & 3 & 7.5 & 104 & 0.87 & $22.85^{*}$ \\
\hline 2 & $\begin{array}{l}\text { The lack of a sufficient } \\
\text { room for faculty members to } \\
\text { use electronic educational } \\
\text { platforms }\end{array}$ & 28 & 70 & 5 & 12.5 & 7 & 17.5 & 101 & 0.84 & $24.35^{*}$ \\
\hline 3 & $\begin{array}{l}\text { The lack of awareness of } \\
\text { some officials of the } \\
\text { importance of using virtual } \\
\text { educational platforms in } \\
\text { teaching }\end{array}$ & 27 & 67.5 & 9 & 22.5 & 4 & 10 & 103 & 0.86 & $21.96^{*}$ \\
\hline 4 & $\begin{array}{l}\text { Poor ability of some } \\
\text { students to use the computer }\end{array}$ & 26 & 65 & 10 & 25 & 4 & 10 & 102 & 0.85 & $19.40^{*}$ \\
\hline 5 & $\begin{array}{l}\text { Weak ability of some } \\
\text { faculty members to use } \\
\text { computers }\end{array}$ & 25 & 62.5 & 10 & 25 & 5 & 12.5 & 100 & 0.83 & $16.25^{*}$ \\
\hline
\end{tabular}

Assiut Journal For Sport Science Arts materials and interaction tools, and linking perception and knowledge. This answers the second question of the research, which states: "To what extent are virtual electronic educational platforms used in teaching the fencing course to male and female students of some faculties of physical education?"

Third, the third axis: "What are the difficulties facing the use of virtual electronic educational platforms in teaching the fencing course to male and female students of some physical education colleges?" 
Table (8)

Frequencies, percentages, relative importance, relative weight, and coefficient (Ca2) for responses of respondents about the difficulties facing the use of virtual electronic educational platforms in teaching the fencing course to male and female students of some physical education colleges, $N=40$

\begin{tabular}{|c|c|c|c|c|c|c|c|c|c|c|}
\hline \multirow[t]{2}{*}{$\overline{\mathbf{S}}$} & \multirow[t]{2}{*}{ Phrases } & \multicolumn{2}{|c|}{ Yes } & \multicolumn{2}{|c|}{ Rather } & \multicolumn{2}{|c|}{ No } & \multirow{2}{*}{$\begin{array}{l}\text { Relative } \\
\text { Imp. }\end{array}$} & \multirow{2}{*}{$\begin{array}{l}\text { Relative } \\
\text { Weight }\end{array}$} & \multirow[t]{2}{*}{$\overline{C a 2}$} \\
\hline & & $\mathbf{F}$ & $\%$ & $\mathbf{F}$ & $\%$ & $\mathbf{F}$ & $\%$ & & & \\
\hline 6 & $\begin{array}{l}\text { The high cost of using } \\
\text { electronic learning platforms. }\end{array}$ & 35 & 87.5 & 4 & 10 & 1 & 2.5 & 114 & 0.95 & $53.16^{*}$ \\
\hline 7 & $\begin{array}{l}\text { The plenty of technical and } \\
\text { technical problems. }\end{array}$ & 32 & 80 & 3 & 7.5 & 5 & 12.5 & 107 & 0.89 & $39.35^{*}$ \\
\hline 8 & $\begin{array}{l}\text { The lack of internet networks } \\
\text { for some students }\end{array}$ & 34 & 85 & 1 & 2.5 & 5 & 12.5 & 109 & 0.91 & $48.66^{*}$ \\
\hline 9 & $\begin{array}{l}\text { Many students are busy with } \\
\text { electronic games and entertainment } \\
\text { programs over the Internet during the } \\
\text { virtual sessions }\end{array}$ & 29 & 72.5 & 5 & 12.5 & 6 & 15 & 103 & 0.86 & $27.65^{*}$ \\
\hline $\begin{array}{l}1 \\
0\end{array}$ & $\begin{array}{l}\text { The lack of interest in colleges } \\
\text { to hold courses and workshops } \\
\text { for faculty members and } \\
\text { students on how to use } \\
\text { educational platforms }\end{array}$ & 25 & 62.5 & 1 & 2.5 & 14 & 35 & 91 & 0.76 & $21.66^{*}$ \\
\hline $\begin{array}{l}1 \\
1\end{array}$ & $\begin{array}{l}\text { Weak infrastructure available } \\
\text { in colleges, from laboratories } \\
\text { and computers to and internet } \\
\text { networks }\end{array}$ & 32 & 80 & 3 & 7.5 & 5 & 12.5 & 107 & 0.89 & $39.36^{*}$ \\
\hline $\begin{array}{l}1 \\
2\end{array}$ & $\begin{array}{l}\text { The difficulty of using } \\
\text { electronic platforms in } \\
\text { teaching the practical and } \\
\text { skills side of some courses }\end{array}$ & 32 & 80 & 3 & 7.5 & 5 & 12.5 & 107 & 0.89 & $39.35^{*}$ \\
\hline
\end{tabular}

"Ca2" value at the level of significance $0.05=(5.99)$.

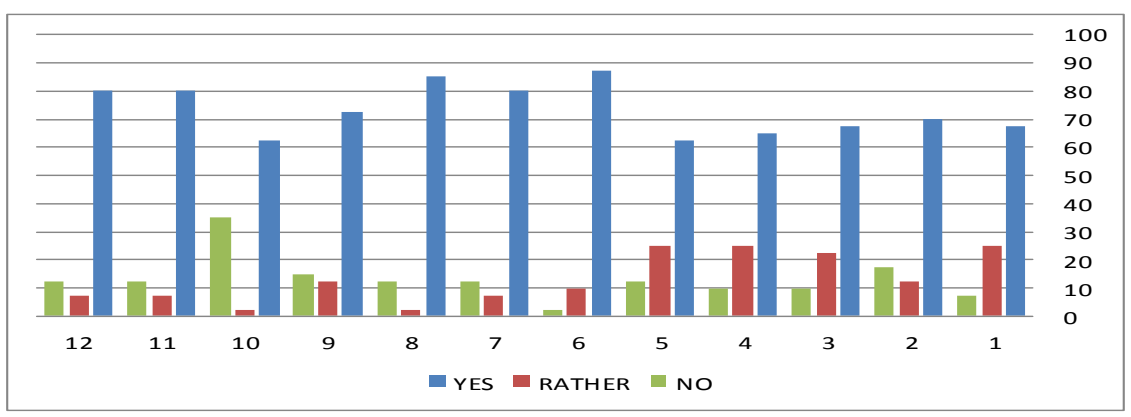

Figure (3)

The Percentage of Frequencies of The expressions of the Third Axis.

Assiut Journal For Sport Science Arts 
It is clear from Table (8) and Figure (3) that The Frequencies, Percentages, Relative Importance, Relative Weight, and The Coefficient (Ca2) for responses of the sample members about the difficulties facing the use of virtual educational platforms in teaching the fencing course to students of some faculties of physical education, "the third axis" ranges The frequency of the answer (yes) is between (25:35) and with a percentage (62.5\%: 87.5\%), and the frequency and percentage of faculty members who answered (Rather) between (1:10) and a percentage $(2.5 \%)$ The frequency and percentages of faculty members who answered (No) were limited to between (1: 14) and with a percentage $(2.5 \%$ : $35 \%$ ), and the calculated $\mathrm{Ca} 2$ value ranged between (16.25: 53.16) greater than its tabular value (5.99) at a degree of freedom (2) at a level of significance (0.05) in all expressions of the third axis.

Whereas, the highest approved phrases were the phrase "The high cost of using electronic educational platforms" by $87.5 \%$. And the least of the expressions that were not approved are "The weak ability of some faculty members to use the computer" as well as the phrase "The lack of interest of colleges in holding courses and workshops for faculty members and students about how to use educational platforms" by $62.5 \%$, and this indicates that there are many Among the difficulties involved in using virtual educational platforms in teaching the fencing course to male and female students of some physical education colleges, especially those related to the budget allocated to electronic education.

It agrees with the study of

Al-Qahtani, Ibtisam Saeed (2010) (6), Al-Sayyid Abd al-Aal Abdullah (2015) (7),Al-Dossari Muhammad Salem (2016) (3), Al-Enezi Yusef Abd al-Majeed (2017) (4 ), AlHamad Hanan Abdulaziz Saud (2019) (5),Al-Rashidy Munira Shuqair (2019) (15), Armitage, J. (2011) (17), Baker, R. \& other (2018). 18), Chung, CH \& other (2018) (19), Zhu, C. (2018) (30).

The researcher believes that there are many difficulties facing the virtual electronic educational platforms, on top of which is the budget allocated to E-education, the slow and continuous disruption of communication networks in some regions, and the lack of Internet networks in all regions.

This answers the third question, which states, "What are the difficulties facing the use of virtual electronic educational platforms in teaching the fencing course to male and female students of some physical education colleges?"

Results related to the fourth question, which states "What is the proposed vision for developing and activating virtual electronic educational platforms in Physical Education Colleges?"

Within the limits of the researcher's findings and in light of the research results, it became clear that there are many difficulties and obstacles facing the use of virtual electronic educational platforms in teaching the fencing course to male and female students in some faculties of physical education. 
The researcher attributes the dependence of all physical education colleges on the traditional system in education, as there are difficulties facing e-learning, including the inability to cover the financial cost necessary to fully use e-learning and the limited availability of the infrastructure that serves communications from computers, laboratories and Internet networks, with the unavailability of platforms Electronic because it matches the cost of care and the lack of training of faculty members and students to use educational platforms. Therefore, the researcher decided to develop a proposed concept to address the deficiencies and problems facing the use of educational platforms. Attachment (5)

\section{Conclusions}

In light of the research procedures, the limits of the basic sample, and statistical analysis, the researcher concluded the following:1-All members of the fencing course faculty agree on the importance of using virtual electronic educational platforms to improve the educational process and the quality of education, as they work to achieve the objectives of the educational process, attract students' attention, and work to impart skills, knowledge and theoretical information.

2-All members of the fencing course faculty agree on the weakness of using virtual electronic educational platforms in teaching the fencing course to students of colleges of physical education.

3- All members of the fencing course faculty agree that there are difficulties facing the use of virtual electronic educational platforms, such as not being able to cover the financial cost necessary to fully use E-learning and educational platforms in particular, and the limited availability of the infrastructure that serves communications from computers, laboratories and Internet networks.

\section{Recommendations}

Based on the results of the research and the conclusions resulting from it, the researcher recommends:

1- Paying attention to training faculty members to use virtual electronic educational platforms.

2-The necessity of providing technicians specialized in operating and maintaining virtual electronic educational platforms in order to facilitate and improve learning.

3-Encouraging the awareness of faculty members to take advantage of virtual educational platforms.

1- Directing the positive trend towards employing virtual classes in Egyptian universities.

2- Making use of virtual educational platforms to spread messages and decisions between learners and some of them. And between the learners and their teachers. 3- The use of educational videos that teach the skills of the course to benefit from the refinement of the practical side of the students.

4- Providing infrastructure and financial support in universities to train students and members of the faculty to use electronic platforms.

\section{References}

\section{First :Arabic references}

1-Abdel Aziz ,Ibrahim Nabil (1998):

"Basics of Fencing", Cairo, Al-Kitab

Center for Publishing.

2-Abu Khotwa , alsyd Abdul Mawla

(2010): "Principles of designing electronic courses derived from learning theories and their educational 
applications", Conference of the ELearning Course in Promoting Knowledge Societies, Zain Center for E-Learning, University of Bahrain from 6-8 / 4/2010 .

3- Al-Dossary , Muhammad Salem Muhammad (2016): "The Reality of Teaching Staff Members Using Electronic Educational Platforms in Teaching English Language at King Saud University," an unpublished Master Thesis, Yarmouk University, Jordan.

4-Al-Enezi ,Yousef Abdel-Majeed (2017): "Effective use of educational platforms" Edmodo "for students of mathematics and computer majors at the College of Basic Education in the State of Kuwait," Published research, Scientific Journal of the College of Education, Assiut University, volume (33) and issue (6).

5-Al-Hamad, Hanan Abdul Aziz Saud (2019): "The reality of the teaching staff's use of electronic educational platforms in teaching forensic sciences, published research, Journal of Scientific Research in Education, Issue (20), Kingdom of Saudi Arabia

6-Al-Qahtani , Ibtisam Saeed (2010): "The reality of using virtual classrooms in the distance education program from the viewpoint of faculty members at King Abdul Aziz University in Jeddah", an unpublished master thesis, Kingdom of Saudi Arabia

7-Al-Sayed ,Abd Al-Aal Abdullah (2015): "Edmodo electronic educational platforms, a future vision for social e-learning environments," scientific research, e-learning journal,
College of Education, Mansoura University, Issue (16).

8-Al-Sayed,Atef Mohamed (2000): "Education and Information Technology, Computer and Video Use in Teaching and Learning", Ramadan Press, Alexandria.

9-Al-Rashidi Munira Choucair (2019): "The reality of using automatic computer teachers for electronic educational platforms in teaching and their attitudes towards it." Master Thesis, Journal of Scientific Research in Education, Issue (20), Kingdom of Saudi Arabia.

10-El Mallah ,Tamer El Maghawry (2017): "The Internet between Communication Technology and Accelerated Learning," 1st Edition University Book House, Alexandria.

11-Hassanein ,Mahdi Saeed (2011): "The Employment of Educational Technology in Distance Learning Programs in the College of Education from the Viewpoint of the Faculty Members", The Palestinian Journal of Open Distance Education, Palestine.

12-Hilal, Reda Mustafa (2008): "Evaluation of educational techniques in teaching physical education curricula at the preparatory stage", published research, Journal of Physical Education Research, Volume (42), Issue (79), College of Education, Yadiyya Benin, Zagazig University.

13-Khamis , Muhammad Atiya (2018): "E-learning Environments, Part 1", Dar Al-Sahab for Publishing and Distribution, Cairo.

14- Omar Laila El-Sayed (2000): "Distance education systems in Sudanese universities," Master Thesis, 
College of Education, University of Khartoum, Sudan.

15-Sukkar, Muhammad Wajih Abd al-Gawad (2003): "The Duel between Education and Training", Al-Masry for Printing.

16-Tamam , Shadia Abdel Halim (2008): "Quality in open education programs in light of global trends and local needs" Arab Publishing House, Cairo.

\section{Second: Foreign references}

17. Armitage, J. (2011). Using Learning Platforms to Support Communication and Effective Learning. International Journal of Virtual and Personal Learning Environments, 2(1), 54-64. IGI Global. 18. Baker, R., Wang, F., Ma, Z., Ma, W. \& Zheng, S. (2018). Studying the Effectiveness of an Online Language Learning Platform in China. Journal of Interactive Learning Research, 29(1), 5-24. Waynesville, NC: Association for the Advancement of Computing in Education (AACE).

19. Chang, B., Shih, Y.A. \& Lu, F.C. (2018). Co Construction Concept Through Cloud-Based Social Network Platform Design, Implementation, and Evaluation. The International Review of Research in Open and Distributed Learning, 19(5),. Athabasca University Press.

20. Chung, C.H., Yu, C.Y. \& Kuo, C.H. (2018). Exploring faculty's using behaviors in LMS platform to improve training programs. In E. Langran \& J. Borup (Eds.), Proceedings of Society for Information Technology \& Teacher Education International Conference (pp. 123-127). Washington, D.C., United States: Association for the
Advancement of Computing in Education (AACE).

21. Dziuban, C., Moskal, P., Cassisi, J. \& Fawcett, A. (2016). Adaptive Learning in Psychology: Wayfinding in the Digital Age. Online Learning Journal, 20(3),. The Online Learning Consortium.

22. El Mabrouk, M., Gaou, S. \& Rtili, M. (2017). Towards an Intelligent Hybrid Recommendation System for E-Learning Platforms Using Data Mining. International Journal of Emerging Technologies in Learning (iJET), 12(6), 52-76. Kassel, Germany: International Association of Online Engineering.

23. Elsayed Ahmed, M. \& Hasegawa, S. (2015). A Proposed Model Combining Instructional Design and Software Engineering for Developing Virtual Learning Platforms. In Proceedings of Global Learn Berlin 2015: Global Conference on Learning and Technology (pp. 654-663). Berlin, Germany, Association for the Advancement of Computing in Education (AACE).

24- Liu, J. (2018). Construction of Real-time Interactive Mode-based Online Course Live Broadcast Teaching Platform for Physical Training. International Journal of Emerging Technologies in Learning (iJET), 13(6), 73-85. Kassel, Germany: International Association of Online Engineering.

25.Wang, H. (2018). Study on the Design of Campus Network-based Personalized English Teaching Platform. International Journal of Emerging Technologies in Learning (iJET), 13(4), 117-128. Kassel, 
Germany: International Association of Online Engineering.

26.Weston, T., Kosko, K., Amador, J. \& Estapa, A. (2018). Preservice Teachers' Questioning: Comparing Platforms for Practice-Based Teacher Education. Journal of Technology and Teacher Education, 26(1), 149-172. Waynesville, NC USA: Society for Information Technology \& Teacher Education.

27.Xi, J., Chen, Y. \& Wang, G. (2018). Design of a Personalized Massive Open Online Course Platform. International Journal of Emerging Technologies in Learning (iJET), 13(4), 58-70. Kassel, Germany: International Association of Online Engineering.
28.Yu, Y. (2016). Construction of Electronic Examination and Education Platform for Financial Management. International Journal of Emerging Technologies in Learning (iJET), 11(9), 14-19. Kassel, Germany: International Association of Online Engineering.

29.Zhang, Y. (2018). Development of WebGL-based Virtual Teaching Platform for Mold Design. International Journal of Emerging Technologies in Learning (iJET), 13(6), 16-28. Kassel, Germany: International Association of Online Engineering.

30. Zhu, C. (2018). Construction of the Network Learning Platform for the Course Building Space Transformation based on Grid. International Journal of Emerging Technologies in Learning (iJET), 13(5), 201-211. Kassel, Germany: International Association of Online Engineering. 